\title{
Natural Disaster Reduction in Coastal Lowland Areas
}

\author{
Shu-e Huang \\ Meteorological Research Institute of Jiangxi Province \\ Nanchang, China
}

\begin{abstract}
In recent years, the impacts of natural disaster are more and more severe on coastal lowland areas. With the threats of climate change and sea level rise, the reduction of natural disasters in coastal lowland areas receives increased attention. Based on a number of literature sources, this paper summarizes the categories and characteristic of natural disasters emerging in coastal lowland areas, such as windstorm and storm surge, tropical cyclones and tropical cyclone winds, tsunamis and floods, and analyzes the most devastating natural disasters in coastal lowland throughout the world in 2005. This paper also summarizes the effects of typhoons on the coastal lowland areas of China in 2005 and analyzes the natural disaster mitigation measures and research results. Finally, the paper discusses the vulnerability assessment and response strategies for natural disasters.
\end{abstract}

\section{Introduction}

The World Meteorological Organization (WMO, 2006) estimates that about 90 percent of all natural disasters is caused by weather, climate, and water. Recently, Munich Reinsurance Company indicated that economic losses from natural catastrophes totaled over U.S. \$160 billion in 2005 (Hoeppe, 2007). The Fourth Assessment report of the WMO/UNEP Intergovernmental Panel on Climate Change (Rosenzweig, et al., 2007) has documented climate-change induced effects in some 100 physical and 450 biological processes. In the Russian Arctic, higher temperatures are melting the permafrost, causing the foundations of five-story apartment buildings to slump. Worldwide, rain is often more intense. Floods and storms are more severe, and heat waves are becoming more extreme. Rivers freeze later in the winter and melt earlier. Trees flower earlier in spring, insects emerge faster, and birds lay eggs sooner. Glaciers are melting and there are indications that the global-mean sea level is rising. The rate of climate change expected over the next 100 years is unprecedented in human history. Sea level rise will increasingly affect coastal margins. But global warming will also alter several other drivers that will impact on coastal areas, such as sediment runoff from land, change in wind and wave patterns, altered ocean currents, warmer sea temperatures, and the expectancy of more intense storms. During the Intergovernmental Panel on Climate Change's (IPCC) Third assessment, it published Planning for Climate Change Effects on Coastal Margins (Bell, et al., 2001).

There are many kinds of natural disasters that can affect coastal lowland areas. For example, numerous natural disasters that affect central Vietnam such as typhoons, river flooding, flash flooding, inundation, landslides, riverbank erosion, coastal erosion, drought, and all other adverse natural phenomena, are preventing sustainable development of the region and thus keeping its inhabitants mired in poverty Food and Agriculture Organization (FAO, 2003). In New Zealand, many coastal zones and small islands experience natural hazards including storms, 
strong winds and heavy rain, subsequent flooding, droughts, submarine geological hazards (under-water landslides and volcanoes), tsunami, sea level rise and climate change, coastal storm surge, extreme tides, hazardous waves, and the resulting coastal inundation and erosion (National Institute of Water \& Atmospheric Research [NIWA, 2005a and 2005d]). Because of these hazards, systems are developed to monitor and predict these extreme events and while humans cannot control the environment, people and communities can mitigate the impact of hazards with preparation and warnings.

\section{Natural Disaster in Coastal Lowland Areas}

\section{Windstorm and Storm Surge}

Worldwide, windstorms (including storm surges) are responsible for a greater number of damaging events than any other type of natural disasters - approximately one-third of all losses owing to nature's forces can be attributed to windstorms. Windstorm damage has been extremely severe in recent decades and it is evident that both the frequency and severity of windstorm disasters have increased (Berz, 2005). Munich Re (2003) indicated that windstorms clearly dominate the catalogue of the costliest natural disasters to the insurance industry. They noted that until 2003, of 37 disasters, which have caused insured losses of U.S. \$1 billion and more, 29 were windstorm disasters, whereas only six stemmed from other types of atmospheric extremes and only two from earthquakes. The research on windstorms mainly includes: generation processes and behavior of severe weather systems, frequency and tracks of cyclones, extreme wind climates, and wind modeling.

According to Federal Emergency Management Agency (FEMA, 2006a), storm surge is defined simply as water that is pushed toward the shore by the force of the winds associated with the storm. This advancing surge of water combines with the normal tides to create the tropical cyclone storm tide, which can increase the mean water level several meters or more. Storm surge can cause severe flooding in coastal areas, particularly when the arrival of the storm coincides with local high tides. FEMA has noted that the greatest potential for tropical-cyclone related deaths is from the storm surge. Storm surges in the southern North Sea pose a complex, persistent, and perhaps growing threat to the surrounding coastline of northwest Europe (Heaps, 1983; Lamb, 1991).

\section{Tropical Cyclones and Tropical Cyclone Winds}

Tropical cyclones are products of the tropical ocean and atmosphere and are powered by heat from the sea. As tropical cyclones make landfall, they can produce storm surge along the coasts, high winds, tornadoes, and both torrential rains and flooding. Coastal communities deciding how strong to make their structures need to consider the strength of tropical cyclone winds and the pressure tropical cyclone winds generate. As winds increase in speed, the pressure against objects or a wall of a house increases with the square of wind speed so that a threefold increase in wind speed gives a nine-fold increase in pressure (ASCE, 2003). For example, a 40 kilometers per hour (kph) or 25 miles per hour (mph) wind causes about 1.6 pounds of pressure per square foot, and a $201 \mathrm{kph}(125 \mathrm{mph})$ wind becomes 1,250 pounds. The American Society of Civil Engineers (ASCE) points out that for some structures, this force is enough to cause 
failure. So far, tropical cyclone research has mainly focused on the mitigation of tropical cyclone damage to people, the economy, and the built and natural environments.

\section{Tsunamis}

Tsunamis are temporary oscillations or waves in the ocean which have periods longer than wind waves or sea swells, but shorter than ocean tides. A tsunami is usually created by a sudden movement or elevation change of the ocean floor from events such as earthquakes, underwater landslides, and underwater volcanic eruptions (NIWA, 2005b). According to the International Tsunami Information Centre (2006a), hosted by the Intergovernmental Oceanographic Commission (IOC) of United Nations Educational, Scientific and Cultural OrganizatioN (UNESCO) http://ioc3.unesco.org/itic, the time between wave crests can range from 5 to 90 minutes, and the speed of the wave in the open ocean can average $724 \mathrm{kph}$ or $450 \mathrm{mph}$. Tsunamis reaching heights of more than 30 meters (100 feet) have been recorded. As the waves approach the shallow coastal waters, they appear normal and the speed decreases. Then as the tsunami nears the coastline, it may grow to great height and crash onto the shore, causing much destruction. Tsunamis occur a few times a year, but generally go unnoticed. Larger tsunami can cause coastal flooding, erosion, damage to buildings, and loss of life in extreme cases.

If a tsunami has been generated, there is no way of estimating the size of the wave. Pacific-wide warnings can generate many hours in advance via the Pacific Tsunami Warning Center in Hawaii run by the U.S. National Oceanic and Atmospheric Administration (NOAA) http://www.prh.noaa.gov/ptwc. There is also the West Coast/Alaska Tsunami Warning Center (http://wcatwc.arh.noaa.gov/), which is responsible for tsunami warnings for the United States in California, Oregon, Washington, Alaska; and the Canadian Province of British Columbia. NOAA provides an online tsunami database at http://www.ngdc.noaa.gov/hazard/tsu.shtml. Tsunami is a disaster that is devastating to the natural and man-made environment. Most deaths during a tsunami are a result of drowning and other hazards include flooding, polluted water supplies, and damaged gas lines (FEMA, 2007).

About half-a-dozen times per century, a tsunami sweeps across the entire Pacific, and sets the entire ocean in motion for days according to the International Tsunami Information Center (ITIC) [ITIC, 2006b]). For example, the 1960 Chilean tsunami caused death and destruction throughout the Pacific with Hawaii, Samoa, and Easter Island all recording waves exceeding 4 miles. From this tsunami, 61 people were killed in Hawaii and 200 in Japan. The ITIC stated that a similar tsunami in 1868 from northern Chile caused extensive damage in the Southern Pacific Islands, Hawaii, Samoa, and New Zealand. Also destructive tsunamis have been generated in the Atlantic and the Indian Oceans and the Mediterranean Sea, though these are not as frequent. ITIC noted that in the last decade, destructive tsunamis have occurred in Nicaragua (1992), Indonesia (1992, 1994, 1996), Japan (1993), Philippines (1994), Mexico (1995), Peru (1996, 2001), Papua-New Guinea (1998), Turkey (1999), and Vanuatu (1999), including the Indian Ocean Earthquake-Tsunami of 2005. The research on tsunamis focus on: tsunami generation, propagation and shoreline impacts; tsunami sources: earthquakes, submarine landslides and volcanoes; historical and geological identification of at-risk coastal areas; sea level, and seismic monitoring for tsunami. 


\section{Flooding}

Coastal flooding is primarily caused by heavy rain events associated with storms (tropical and extra-tropical storms) and storm surges, which were discussed previously. Tropical cyclones (hurricanes) are capable of producing copious amounts of flash flooding rainfall (FEMA, 2006d). During landfall of a tropical cyclone, rainfall can commonly exceed 254 to 381 millimeters (10 to 15 inches). A slow moving storm (less than $16 \mathrm{kph}$ ) can generate even more excessive rainfall. Heavy rain usually occurs slightly to the right of the cyclone track and usually occurs between 6 hours before and 6 hours after landfall. FEMA noted that flooding from tropical cyclones can occur hundreds of miles from the coast putting areas which would not normally be affected by the strongest winds in great danger. Freshwater floods accounted for more than half (59 percent) of U.S. tropical cyclone deaths over the past 30 years (NWS, 2006). Over the past 30 years, 78 percent of children killed by tropical cyclones drowned in freshwater floods (FEMA, 2006d).

According to the FAO (2003) report on Vietnam, floods of long duration can cause severe social impacts during the flood. Health is a grave concern for people suffering from flooding, especially for elderly and disabled family members living in poor conditions with limited food stocks, unclean water sources, and poor sanitation. The report adds that children are most at risk from flooding and that schooling can be disrupted for long periods, especially when buildings are being repaired.

Floods are very common in most coastal countries, especially to New Zealand. Since most New Zealand cities are situated on the coast and many are near rivers, they are at risk from sea or river flooding (NIWA, 2005c). However, a major contributor to coastal flooding in New Zealand is high tides, which can be forecast well in advance. Most rivers have protection against flooding from tides, but if a storm surge or river flood occurs at the same time as the strongest tides, serious flooding can occur. In New Zealand, the National Institute of Water \& Atmospheric Research (NIWA) [2005c]) has developed a series warning of dates for the public. One of these are called "Red-Alert" dates which can be generated when a minor storm surge or river flood could cause coastal flooding because the tides are extreme for those dates. Also, a set of "Carefree" dates can be generated when there is little danger of coastal flooding unless there is a large storm surge or river flood. Predicted Red-alert and Carefree dates can be applied for other places around the world. In some places, the dates of maximum tide height will be a day or two different from those forecasted and the high tide height on some of those days may be nothing unusual.

The research on floods includes: (a) historic rainfall and flood data and risk assessment; (b) flood forecasting using coupled weather and hydrological models; (c) inundation from river- and coastal-flooding dependence on climate-flood mapping to reduce future losses.

\section{Natural Disasters in Coastal Lowland Areas in 2005}

Understanding the magnitude of disaster losses is important for a wide range of decisions, including evaluating the effectiveness of disaster mitigation and understanding trends in vulnerability. 


\section{Indian Ocean Earthquake: Tsunami 2005}

In the early morning hours of Sunday, December 26, 2004, a massive earthquake measuring 9.0 on the Richter scale struck the west coast of northern Sumatra with an epicentre located some 30 kilometres under the seabed and 250 kilometres south-southwest of Banda Aceh (OCHA, 2005). The earthquake triggered powerful tsunamis reaching 10 metres in height, and these moved through neighboring parts of the Indian Ocean at over 500 kilometres an hour wrecking coastal areas in India, Indonesia, Sri Lanka, Thailand, and the Maldives, as well as in Myanmar, the Seychelles, and Somalia. With a death toll of about 350,000, the Indian Ocean tsunami was unique among large disasters in recorded human history, not only because of the sheer number of causalities and massive displacement of people, but also because of the unprecedented international donor response and the logistical challenges faced by international organizations and aid agencies in organizing and coordinating relief efforts (Athukorala, 2005).

The tsunami flooded coastal areas and destroyed homes and buildings, roads and bridges, water and electrical supplies, crops, irrigation and fishery infrastructure, and food and fuel networks. In the affected areas, economic life stopped, many businesses have collapsed, and millions of people have seen their families and communities torn apart. The disaster predominantly affected poor communities where people lived on marginal land.

A flash appeal for aid was made to the worldwide community soon after the event and is summarized below (OCHA, 2005). This appeal for aid reflected the efforts of some forty United Nations (UN) agencies and non-governmental organizations (NGOs) to plan and implement a strategic, efficient, and coordinated response to the needs of some 5 million people. There were programmes that focused on keeping people alive and supporting their efforts to recover in the agriculture, education, health, food, shelter, or water and sanitation sectors. Reaching isolated communities was a serious challenge because of the destruction of transport infrastructures and communication systems and required the establishment of complex logistics and operations platforms. A "Flash Appeal” focused on supporting people in Indonesia, the Maldives, Myanmar, the Seychelles, Somalia, and Sri Lanka from January until the end of June 2005, and called for U.S. \$977 million to fund the critical work. Table 1 shows the breakdown of financial requirements by country and sector.

Table 1. Financial Requirements - By Country and Sector (U.S. dollars)

\begin{tabular}{|c|c|c|c|c|c|c|c|}
\hline Sector & Indonesia & Maldives & Seychelles & Somalia Sri & Lanka & Regional & Grand Total \\
\hline Agriculture & $10,400,000$ & & & $1,925,000$ & & $1,600,000$ & $13,925,000$ \\
\hline $\begin{array}{l}\text { Coordination and Support } \\
\text { Services }\end{array}$ & $14,854,203$ & $7,460,000$ & 300,000 & $5,401,369$ & $21,159,491$ & $93,411,200$ & $142,586,263$ \\
\hline $\begin{array}{l}\text { Economic Recovery and } \\
\text { Infrastructure }\end{array}$ & $17,250,000$ & $11,652,000$ & $7,500,000$ & & $48,960,475$ & $24,400,000$ & $109,762,475$ \\
\hline Education & $12,330,000$ & $8,064,000$ & & & $5,525,340$ & $1,100,000$ & $27,019,340$ \\
\hline $\begin{array}{l}\text { Family Shelter and Non-food } \\
\text { Items }\end{array}$ & $177,160,000$ & $19,100,000$ & $1,100,000$ & 496,000 & $23,160,000$ & $1,000,000$ & $222,016,000$ \\
\hline Food & $3,000,000$ & & & $1,869,000$ & & $209,900,000$ & $214,769,000$ \\
\hline Health & $69,610,000$ & $10,605,000$ & & 275,220 & $28,600,000$ & $12,700,000$ & $121,790,220$ \\
\hline Mineaction & $21,850,000$ & & & $4,232,000$ & & & $4,232,000$ \\
\hline Multi-sector & & & & 212,829 & $4,942,000$ & $2,710,000$ & $29,714,829$ \\
\hline $\begin{array}{l}\text { Protection//Human } \\
\text { Rights/ Rule of Law }\end{array}$ & $15,100,000$ & $1,520,000$ & & & $5,634,000$ & $4,887,500$ & $27,141,500$ \\
\hline Security & $3,000,000$ & & & & & 200,000 & $3,200,000$ \\
\hline Water and Sanitation & $27,000,000$ & $8,096,000$ & & & $24,722,840$ & $1,000,000$ & $60,818,840$ \\
\hline Grand Total & $371,554,203$ & $66,497,000$ & $8,900,000$ & $10,179,418$ & $166,936,146$ & $352,908,700$ & $976,975,467$ \\
\hline
\end{tabular}

(Source from OCHA, 2005). 
The tropical cyclone impacts in United States: The tropical cyclone season in the United States during 2005 was the busiest one ever recorded (Table 2).

Table 2: The total of tropical storm with names for the 2005 Hurricane Season in the United States in comparison to 2004.

\begin{tabular}{|l|l|l|l|}
\hline Parameter & 2005 Season & 2004 season & $\begin{array}{l}\text { Hurricanes average } \\
(1950-2002)\end{array}$ \\
\hline $\begin{array}{l}\text { Total of Tropical Storms with Names } \\
\text { (TS+H) }\end{array}$ & 28 & 14 & 10 \\
\hline
\end{tabular}

(Source: NHC, 2005, 2006, and 2007).

Knabb, et al., (2006) summarized the impacts of Hurricane Katrina which hit the southern United States in August 2005. They stated that Hurricane Katrina was an extraordinarily powerful and deadly hurricane that caused catastrophic damage across a large area and inflicted a large loss of life. Katrina was the costliest and one of the five deadliest hurricanes to ever strike the United States. They noted that considering the scope of its impacts, Katrina was one of the most devastating natural disasters in the history of the United States.

Pielke (2005) stated that based on data available from the National Hurricane Center (NHC) in the United States, the top five storms ranked by total damage in 2004 dollars were: (1) Katrina, \$125B; (2) Andrew, \$26.5B; (3) Charlie, \$15B; (4) Ivan, \$14.2B; and (5) Frances, \$8.9B. He also stated that simply looking at the total costs can be misleading because storms struck in the past encountered very different levels of development and population along the coast. Therefore, previous storms would cause far more damage were they to hit with today's levels of coastal development.

\section{The Typhoon Impact in China}

China suffered from storm surges, floods, rainstorms, and winds in 2005. Disasters were various, emergent, and damaged large areas. According to incomplete statistics from a division of forecast and disaster relief under China's Meteorological Administration, the direct economic losses from meteorological disasters were high at RMB 185.6 billion (almost U.S. \$23 billion), and the damage in 2005 was higher than in 2004. The typhoon disasters were severe in 2005, hitting 11 coastal provinces that all suffered from meteorological disasters; in fact, regarding economic damage, it was one of the most severe disaster years in coastal lowland area since 1949. The direct economic losses resulting from storm surges reached RMB 33 billion (almost U.S. \$4.1 billion). There were nine named storms this season (Table 3) and six out of eight tropical storms landing in China belonged to powerful typhoons.

\section{Natural Disaster Mitigation Measures and Research}

The purpose of disaster mitigation in most coastal lowland area aims to identify geographic areas and development sectors that are at risk for natural disasters and to propose solutions to the development problem of natural disaster vulnerability. These solutions fall within the realm of natural disaster preparedness and natural disaster mitigation. It is impossible to prevent most natural disasters. On the other hand, natural disaster mitigation and the reduction of the effects of natural disasters on humankind and the environment are often attainable. Natural disaster mitigation measures must be incorporated into the design and implementation of all development 
projects and programs in most coastal lowland areas if development is to be sustained. To optimize natural-disaster mitigation, a mix of non-structural and structural strategies must be considered. Typical non-structural natural disaster measures include: (1) disaster response including rescue and evacuation planning; (2) disaster area mapping and zoning; (3) disaster warning systems; (4) grassroots disaster preparedness training and planning; and (5) river basin planning. Typical structural natural disaster measures include: (1) reservoir and dam safety; (2) river and estuary dykes; (3) coastal and river erosion protection; (4) estuary and port dredging; (5) saltwater intrusion barriers; and (6) new flood control reservoirs United Nations Development Programme (UNDP, 2006).

Table 3. National disaster declarations in 2005 for typhoons in China.

\begin{tabular}{|c|c|c|c|c|c|c|c|c|c|}
\hline $\begin{array}{l}\text { Typhoon } \\
\text { name }\end{array}$ & Haitang & Washi & Matsa & Sanvu & Talim & Khanun & Vicente & Damrey & Longwang \\
\hline Province & $\begin{array}{l}\text { Liaoning } \\
\text { Hebei } \\
\text { Tianjing } \\
\text { Shandong } \\
\text { Jiangsu } \\
\text { Shanghai } \\
\text { Fujian } \\
\text { Zhejiang } \\
\text { Guangdong } \\
\text { Guangxi } \\
\text { Hainan }\end{array}$ & $\begin{array}{l}\text { Guangdong } \\
\text { Hainan }\end{array}$ & $\begin{array}{l}\text { Zhejiang } \\
\text { Shanghai } \\
\text { Jiangsu } \\
\text { Shandong } \\
\text { Tianjing } \\
\text { Hebei } \\
\text { Liaoning }\end{array}$ & $\begin{array}{l}\text { Guangdong } \\
\text { Fujiang }\end{array}$ & $\begin{array}{l}\text { Fujiang } \\
\text { Zhejiang }\end{array}$ & $\begin{array}{l}\text { Zhejiang } \\
\text { Shanghai } \\
\text { Jiangsu } \\
\text { Shandong }\end{array}$ & $\begin{array}{l}\text { Hainan } \\
\text { Guangdong }\end{array}$ & $\begin{array}{l}\text { Hainan } \\
\text { Guangdon } \\
\text { Guangxi }\end{array}$ & Fujian \\
\hline
\end{tabular}

FEMA (2006c) provides several measures, at the individual and community levels, to reduce the vulnerability to tropical cyclone hazards. These measures include simple construction measures, such as the use of storm shutters over exposed glass, and the addition of tropical cyclone straps to hold the roof of a structure to its walls and foundation. In addition, more complex mitigation measures can be pursued to further reduce a property's susceptibility. It is recommended that coastal homes and businesses be elevated to permit coastal storm surge to pass under living and working spaces. The adoption and enforcement of wind- and flood-resistant building codes can further reduce the vulnerability of communities to tropical cyclones. Proper land-use planning can ensure that structures are not built in the high risk areas.

Since resources are limited, it impossible to take all of the actions needed to protect every area and its population. Therefore, careful selection and ranking of programs and projects are required to develop an optimal natural disaster mitigation strategy. NIWA (2005a) states that by combining the expertise of atmospheric and river and coastal specialists, one can identify the likelihood of extreme events; monitor and understand key elements of weather, river and coastal systems; identify vulnerable hot-spots with increased risk; and develop computer hazards models, leading to improved forecasts and warnings. Also, by working with the national and regional governments, one can translate the research and models into risk evaluation, timely warning systems, and hazard maps and provide better community planning and increased community resilience to natural hazards.

Early warning systems are an important element of natural disaster mitigation. In the context of the Indian Ocean Tsunami in 2005, the UN's Office for the Coordination of Humanitarian Affairs (OCHA, 2005) stated that the objectives of early warning include the following: the rapid boosting of the capacities for action and planning by public authorities; and linking the available 
technical capacities on natural disasters with humanitarian and emergency management capacities. Also the activities of early warning were to quickly assess the warning capacities of the region, establish interim networks, conduct regional meetings for both training and coordination, develop interim information materials, and provide necessary coordination and support. The expected impacts are the improved public confidence and security, provision of authoritative information products to the humanitarian community, and sound foundations for coordination and informed implementation of early warning systems.

After a tsunami struck the Pacific coast of Nicaragua in 1992, causing significant damage and deaths along the coastal areas of the country, there has been some progress in the region in dealing with these kinds of events. In 2003, a Hemispheric Conference on Early Warning was held in Antigua, Guatemala (ISDR, 2005). This Conference allowed the region to prepare for the Second International Conference on Early Warning (EWC-II: http://www.ewc2.org) that took place later in 2003 which led to the creation of the "Central American Program for Tsunami Warnings.” After the Indian Ocean tsunami in December 2004, this issue reemerged at the regional and international levels, with renewed efforts to establish a Regional Early Warning System in Central America. In May, 2005 the Regional Workshop for establishing a "Program for a Tsunami Early Warning System in Central America” took place in Managua, Nicaragua (ISDR, 2005) and was organized by the Coordination Center for the Prevention of Natural Disasters in Central America (CEPREDENAC) and the Nicaraguan Institute of Territorial Studies (INETER). Many experts in the fields of seismology, geology, oceanography, education and training, as well as civil protection officials, members of Central American National Emergency Commissions, and international participants met in Managua to identify projects, elements, and activities that will contribute to establishing a Tsunami Early Warning System in Central America.

New Zealand's National Institute of Water \& Atmospheric Research (NIWA 2005e) lists several remote sensing techniques for collecting environmental data that have many applications. They are routinely using high resolution satellite imagery to support many natural hazard and risk studies both in New Zealand and in other countries. The imagery is used in mapping building and community infrastructure characteristics and in presenting future risk reduction initiatives. The use of satellite-derived topography allows them to map flood risk over large areas for the insurance industry. Additionally, the use of remotely sensed data is at the center of NIWA's efforts to accurately predict weather-related hazards. They use radar data to estimate rainfall, and then use those estimates to validate the predictions of computer weather models and the resulting rainfall forecasts which are outputs from those models and an essential input into the river flow and flood forecasting (NIWA, 2005e).

NIWA (2005e) also has undertaken three main research themes on the prediction and monitoring of natural disasters: (1) understanding extreme weather systems and developing meteorological computer models to better predict extreme weather events; (2) improving the knowledge of floods and droughts, their risk in different regions, and developing river flood models; (3) understanding the dynamic nature of coastal environments, their propensity for generating extreme events, the effects of climate change, and translating this information into better warning systems, community awareness and preparedness programmes, and consistent planning and policy for coastal areas. 


\section{Vulnerability Assessment and Response Strategies}

\section{Vulnerability Assessment}

According to FEMA (2006b), hazard mitigation planning is an important aspect of a successful mitigation program. Local communities use the hazard mitigation planning process to set short and long-range mitigation goals and objectives. They also state that hazard mitigation planning is a collaborative process where hazards affecting the community are identified, hazard vulnerabilities are assessed, and a consensus is reached on minimizing or eliminating the effects of these hazards. Vulnerability to impacts is a multi-dimensional concept, encompassing biogeophysical, economic, institutional, and socio-cultural aspects (Klein and Nicholls, 1999).

The Intergovernmental Panel on Climate Change’s (IPCC) common methodology defines vulnerability as "the degree of incapability to cope with the consequences of climate change and accelerated sea level rise” (IPCC and CZMS, 1991). Therefore, an analysis of the vulnerability of a coastal area or small island to climate change includes a notion of its susceptibility to the bio-geophysical effects of climate change and sea level rise, as well as of its natural resilience which is greatly influenced by past, current, and future population; settlement patterns; and rates of socioeconomic change. The report states that both susceptibility and resilience determine the natural system's sensitivity to anticipated changes. Other reports indicated that socioeconomic vulnerability is further determined by a country's technical, institutional, economic, and cultural capabilities to cope with or manage the anticipated bio-geophysical effects and their consequent socio-economic impacts (WCC, 1994). The IPCC common methodology has helped to focus the attention of many coastal nations on climate change and has contributed to long-term thinking about the coastal zone (Dolan and Walker, 2003). On the other hand, a number of problems have been raised concerning the common methodology through the experiences of vulnerability assessment case studies. Although the common methodology has encouraged researchers to take into account the bio-geophysical response of the coastal system to sea level rise, lack of data and models for describing local coastal processes and responses have hindered detailed, quantitative impact assessments. Many case studies have carried out a simple first-order assessment by horizontally shifting the coastline landward by an amount corresponding with the sea-level rise scenario. More attention should be paid to broader socioeconomic evaluation techniques, which include traditional, aesthetic, and cultural values Bijlsma, et al., 1996).

In many industrialized countries, the main potential losses from sea level rise seem to be coastal wetlands, as well as sandy beaches in some countries. However, a change in the frequency, intensity, or distribution of extreme weather events could have implications for urban area and related capital assets in countries such as Japan, Australia, the United States, and some countries bordering the North Sea. The global vulnerability assessment (GVA) has provided estimates of the following impacts: 1 ) population at risk - the average number of people per year subject to flooding by storm surge on a global scale; 2) wetlands at loss - the ecologically valuable coastal wetland area under serious threat of loss on a global scale; 3) and rice production at change - the changes in coastal rice yields as a result of less-favorable conditions due to sea level rise in southern, southeastern, and eastern Asia (WCC, 1994). 


\section{Response Strategies}

There is no doubt that the threat of climate change and sea level rise has focused attention on coastal zones and small islands and awakened awareness of the vulnerability of the world's coastal regions in general and to low-lying coasts, tidal deltas, and small islands in particular. IPCC and CZMS $(1990,1992)$ have distinguished three groups of response strategies: retreat, accommodate, and protect. The first involves strategic retreat from or the prevention of future major developments in coastal areas that may be impacted. The second includes adaptive responses such as elevation of buildings, modification of drainage systems, and land-use changes. Both strategies are based on the premise that increases in land loss and coastal flooding will be allowed to occur and that some coastal functions and values will change or be lost. On the other hand, these strategies help to maintain the dynamic nature of coastal ecosystems and thus allow them to adapt naturally. The third strategy involves defensive measures and seeks to maintain shorelines at their present position by either building or strengthening protective structures or by artificially nourishing or maintaining beaches and dunes. This function could involve the loss of natural functions and values.

The International Strategy for Disaster Reduction (ISDR) has put forward the Hyogo Framework for action 2005-2015: Building the Resilience of Nations and Communities to Disasters (http://www.unisdr.org/eng/hfa/hfa.htm). ISDR recognizes priority areas in the reduction of the underlying risk factors for building a safer world and identifies a number of measures that will help reduce the impact of hazards on poor populations. However, to achieve the Millennium Developments Goals and reduce poverty before 2015, the world must find mechanisms that work and actively implement them.

There are many problems in the disaster deduction, such as development problems, poverty problems, and institutional problems. Development is extremely difficult to sustain when progress is repeatedly set back by natural disasters. An effective natural disaster mitigation strategy must incorporate opportunities for socio-economic development into its policy framework and its mitigation plans. There are poverty problems in coastal lowland areas in some developing countries, for example in Vietnam. The people most affected by natural disasters are the least able to cope with the effects of the disaster. While incorporating development opportunities into the disaster mitigation framework, special attention must be given to poverty reduction and hunger eradication. By soliciting the participation of the people most directly affected by natural disasters through a grassroots participatory approach, the afflicted communities will become empowered and share a sense of ownership of the projects they have developed. This empowerment and self-determination are the foundations of sound and sustainable socio-economic development. In natural disaster deduction, people also aim at the institutional problems and provide an opportunity for the development of institutions that will coordinate, manage, and implement disaster mitigation programs and projects. These institutions will operate on every level, from the local level in the hamlet and commune up to the central government level of a state. 


\section{Conclusions}

1) Ninety percent of all natural disasters are caused by weather, climate, and water worldwide.

2) The total damage due to weather disasters reached a historic level in 2005.

3) Severe natural disasters are becoming more frequent and the effects are becoming more devastating on coastal lowland areas.

Author E-mail Contact: jxhse@sohu.com

\section{References}

ASCE. 2003. Hurricane's Aftermath Can Leave Trail of Devastation: What Can You Expect? http://www.asce.org/pressroom/news/display_press.cfm?uid=1469

Athukorala, P.C. and B.P. Resosudarmo, 2005. The Indian Ocean Tsunami: Economic Impact, Disaster Management and Lessons. Paper presented at the Asian Economic Panel Conference, Keio University, Tokyo. 1-56 pp.

Bell, R.G., T.M. Hume, and D.M. Hicks. 2001. Planning for Climate Change Effects on Coastal Margins. New Zealand Climate Change Programme. Ministry for the Environment. Wellington, New Zealand. http://www.mfe.govt.nz/publications/climate/effect-coastal-sep01/index.html

Berz G. 2005. Windstorm and storm surges in Europe: loss trends and possible count-actions from the viewpoint of an international reinsurer. Phil. Trans. R. Soc. A, 363. 1431-1440 pp.

Bijlsma, L., C.N. Ehler, and R.J.T. Klein, and others. 1996. Coastal zones and small islands. In Watson, R.T., Zinyowera, M.C. and Moss, R. H. (eds.) Climate Change 1995: Impacts, Adaptations and Mitigation of Climate Change. Cambridge University Press: Cambridge. 291324 pp.

Dolan, A.H. and I.J. Walker, 2003. Understanding vulnerability of coastal communities to climate change related risks. Journal of Coastal Research, SI 39 (Proceedings of the 8th International Coastal Symposium), Santa Catarina - Brazil, ISSN: 0749-0208.

FEMA. 2006a. Hurricane Hazards: Storm Surge. http://www.fema.gov/hazard/hurricane/hu_surge.shtm (accessed 16 January 2006).

FEMA. 2006b. Hurricanes: Disaster Prevention - Recovery. FEMA Web page. http://www.femadocuments.com/article.cfm/id/32562 (accessed 16 January 2006).

FEMA. 2006c. Surviving the Storm. A Guide to Hurricane Preparedness.

http://www.fema.gov/pdf/library/survivingthestormhurricane.pdf (accessed 16 January 2006).

FEMA. 2006d. Hurricane Hazards: Rainfall and Flooding. http://www.fema.gov/hazard/hurricane/hu_flood.shtm (accessed 20 January 2006). 
FEMA. 2007. Tsunami. http://www.fema.gov/hazard/tsunami/index.shtm (accessed 15 Jul 2007).

FAO. 2003. The Role of Local Institutions in Reducing Vulnerability to Recurrent Natural Disasters and in Sustainable Livelihoods Development Case Study: Vietnam. Submitted by the Asian Disaster Preparedness Center. ftp://ftp.fao.org/docrep/fao/007/ae080e /ae080e00.pdf

Heaps, N.S. 1983. Stormsurges, 1967-1982. Geophys, J. R. Astr. Soc., 74. 331-376 pp.

Hoeppe, P. 2007. Scientific and Economic Rationale for Weather Risk Insurance for Agriculture. In Sivakumar MVK, Motha R (Eds.) Managing Weather and Climate Risks in Agriculture. Springer, Berlin Heidelberg. 367-375 pp.

IPCC and CZMS. 1990. Strategies for adaptation to sea level rise. Eds. R. Misdorp, J. Dronkers and J.R.Spradley. Intergovernmental Panel on Climate Change, Response Strategies Working Group, Coastal Zone Management Subgroup. Ministry of Transport and Public Works, The Hague.

IPCC-Coastal Zone Management Subgroup (CZMS). 1991. The Seven Steps to Vulnerability Assessment of Coastal Areas to Sea-Level Rise-A Common Methodology. Report of the Coastal Zone Management Subgroup. IPCC Response Strategies Working Group, Revision No. 1.

IPCC Coastal Zone Management Subgroup (CZMS). 1992. Global climate change and the rising challenge of the sea. Eds. L. Bijlsma, J. OpCallaghan, R. Hillen, and R. Misdorp, et al., Intergovernmental Panel on Climate Change, Response Strategies Working Group, Coastal Zone Management Subgroup. Ministry of Transport and Public Works, The Hague.

ISDR. 2005. Regional Workshop: "Program for a Tsunami Early Warning System in Central America” http://www.eird.org/eng/revista/n11_2005/art18.htm

ITIC. 2006a. FAQS: How Does Tsunami Energy Travel Across the Ocean and How Far Can Tsunamis Waves Reach? http://ioc3.unesco.org/itic/contents.php?id=164 (accessed 10 January 2006.

ITIC. 2006b. FAQS: Where and How Frequently are Tsunamis Generated? http://ioc3.unesco.org/itic/contents.php?id=163 (accessed 15 January 2006).

Klein, R.J.T. and Nicholls, R.J., 1999. Assessment of coastal vulnerability to climate change. Ambio, 28, 2. 182-187 pp.

Knabb, R.D., J.R. Rhome, and D.P. Brown, 2006. Tropical Cyclone Report: Hurricane Katrina 23-30 August 2005. National Hurricane Center. Miami, FL, USA. http://www.nhc.noaa.gov/pdf/TCR-AL122005_Katrina.pdf

Lamb H.H. 1991. Historic storms of the North Sea, British Isles and Northwest Europe, P. xi. Cambridge: Cambridge University Press. 204 p. 
Munich Re. 2003. Annual review of natural catastrophes 2002. Munich: Munich Reinsurance Company. 48 p.

NIWA. 2005a. Mitigating Weather, Flooding and Coastal Hazards. http://www.niwa.cri.nz/rc/prog/c01x0218 (accessed on 1 Dec 2005).

NIWA. 2005b. Physical Hazards Affecting Coastal Margins and the Continental Shelf. http://www.niwa.cri.nz/rc/prog/chaz/news/tsunami (accessed on 1 Dec 2005).

NIWA. 2005c. Red Alert days for coastal flooding. http://www.niwascience.co.nz/rc/prog/chaz/news/coastal\#red (accessed on 1 Dec 2005).

NIWA. 2005d. Hazards. http://www.niwa.cri.nz/rc/hazards (accessed on 1 Dec 2005.)

NIWA. 2005e. Natural Hazards Update - No.6 November 2005.

http://www.naturalhazards.net.nz/publications/ma/2005-06 (accessed on 1 Dec 2005).

NHC. 2007. 2005 Atlantic Hurricane Season. http://www.nhc.noaa.gov/2005atlan.shtml

NHC. 2005. 2004 Atlantic Hurricane Season. http://www.nhc.noaa.gov/2004atlan.shtml

NHC. 2006. Tropical Cyclone Climatology. http://www.nhc.noaa.gov/pastprofile.shtml

NWS. 2006. Flood safety. http://www.nws.noaa.gov/floodsafety/trop.shtml (accessed 20 January 2006).

OCHA. 2005. Consolidated Appeals Process (CAP): Flash Appeal 2005 for Indian Ocean Earthquake - Tsunami. http://ochadms.unog.ch/quickplace/cap/main.nsf/h_Index/Flash_2005_IndianOceanTsunami/\$FI LE/ Flash_2005_IndianOceanTsunami_SCREEN.PDF?OpenElement and http://www.reliefweb.int/appeals/temp/FlashAppeal/Flash_2005_IndianOceanTsunami.pdf

Pielke Jr., R. 2005. Normalized Hurricane Damage in the United States. http://sciencepolicy.colorado.edu/prometheus/archives/disasters/000563part_ii_historical.html (Accessed 5 December 2005).

Rosenzweig, C., G. Casassa, D.J. Karoly, A. Imeson, C. Liu, A. Menzel, S. Rawlins, T.L. Root, B. Seguin, and P. Tryjanowski, 2007. Assessment of observed changes and responses in natural and managed systems. Climate Change 2007: Impacts, Adaptation and Vulnerability. Contribution of Working Group II to the Fourth Assessment Report of the Intergovernmental Panel on Climate Change, M.L. Parry, O.F. Canziani, J.P. Palutikof, P.J. van der Linden, and C.E. Hanson, Eds., Cambridge University Press, Cambridge, UK. 79-131 pp.

World Coast Conference (WCC). 1994. Preparing to Meet the Coastal Challenges of the 21st Century. World Coast Conference Report, Noordwijk, Nov. 1993, Rijkswaterstaat, The 
Netherlands. The Hague: Ministry of Transport, Public Works, and Water Management. National Institute for Coastal and Marine Management, Coastal Zone Management Centre.

UNDP. 2006. Structural and non-structural measures for prevention and mitigation of damage caused by natural disasters. http://www.undp.org.vn. (Accessed 16 January 2006).

WMO, 2006. WMO at a Glance. WMO Publication 990. Geneva, Switzerland. 